\title{
Do the new triatomine species pose new challenges or strategies for monitoring Chagas disease? An overview from 1979-2021
}

\author{
Jane Costa ${ }^{1 /}$, Carolina Dale', Cleber Galvão², Carlos Eduardo Almeida ${ }^{3,4}$, Jean Pierre Dujardin ${ }^{5}$ \\ ${ }^{1}$ Fundação Oswaldo Cruz-Fiocruz, Instituto Oswaldo Cruz, Laboratório de Biodiversidade Entomológica, Rio de Janeiro, RJ, Brasil \\ ${ }^{2}$ Fundação Oswaldo Cruz-Fiocruz, Instituto Oswaldo Cruz, Laboratório Nacional e Internacional de Referência em Taxonomia de Triatomíneos, \\ Rio de Janeiro, RJ, Brasil \\ ${ }^{3}$ Universidade Federal da Bahia, Salvador, BA, Brasil \\ ${ }^{4}$ Universidade Estadual de Campinas, Instituto de Biologia, Campinas, SP, Brasil \\ ${ }^{5}$ Institut de Recherche pour le Développement, Montpellier, France
}

Chagas disease persists as one of the most important, and yet most neglected, diseases in the world, and several changes in its epidemiological aspects have been recorded since its discovery. Currently, some of the most relevant changes are related to: (i) the reduction in the incidence of the endemic due to the control of the most important vectors, Triatoma infestans and Rhodnius prolixus, in many countries; (ii) the migration of human populations spreading cases of the disease throughout the world, from endemic to non-endemic areas, transforming Chagas disease into a global threat; and (iii) new acute cases and deaths caused by oral transmission, especially in the north of Brazil. Despite the reduction in the number of cases, new challenges need to be responded to, including monitoring and control activities aiming to prevent house infestation by the secondary vectors from occurring. In 1979, Lent \& Wygodzinsky ${ }^{(1)}$ published the most complete review of the subfamily Triatominae, encompassing 111 recognised species in the taxon. Forty-two years later, 46 new species and one subspecies have been described or revalidated. Here we summarise the new species and contextualise them regarding their ecology, epidemiologic importance, and the obstacles they pose to the control of Chagas disease around the world.

Key words: American Trypanosomiasis - vectors - Triatominae subfamily

Despite the great achievements in controlling Chagas disease, also known as American Trypanosomiasis, major problems are still to be solved in Latin American countries. $^{(2)}$ No vaccines or drugs are currently available to cure the chronic phase of this disease that affects six million people around the world and has its epidemiology constantly changing because of ecological, climatic, social, political, and technical factors..$^{(3,4,5,6)}$

The most effective action in terms of Chagas disease control is the elimination of its vectors from the human dwellings $^{(7)}$ and, as a means to achieve this goal, four multigovernmental initiatives were launched (South America, Andean countries, Mexico and Central America, Amazon) targeting the three most important triatomine species that transmit the etiological agent Trypanosoma cruzi: Triatoma infestans (Klug, 1834) (southern South America), Rhodnius prolixus Stål, 1859, and T. dimidiata (Latreille, 1811) (northern South America and Central America). The most remarkable achievement resulting from these initiatives was the elimination of the T. infestans domiciliated populations in Brazil, Chile,

doi: 10.1590/0074-02760210015

Financial support: CNPq, FAPESP (process no. 2016/08176-9), FAPERJ.

JC, CEA and CG are CNPq Research Productivity Granted - PQ-2

(303363/2017-7, 306357/2019-4, and 305182/2019-6).

+ Corresponding author: jcosta@ioc.fiocruz.br

(D) https://orcid.org/0000-0001-6664-1394

Received 14 January 2021

Accepted 04 May 2021
Uruguay, various provinces in Argentina, and several regions in Paraguay. ${ }^{(8)}$ More recently, the elimination of the domiciliary infestations of $R$. prolixus from Central America. ${ }^{(9,10)}$ has also been considered a significant accomplishment regarding the battle against vectorial Chagas disease transmission.

Carlos Chagas $^{(11)}$ described the disease in 1909, when the great majority of cases were due to vectorial transmission by the triatomine bug T. infestans, the species most well adapted to human dwellings in many countries in Latin America. Later, several other possibilities of transmission were attested, such as those observed as the result of the donation of infected blood or organs, or the ingestion of contaminated food, mother-child transmission and because of laboratory work accidents. ${ }^{(12,13,14)}$

More than 10 years after the certification of the elimination of the vectorial transmission by $T$. infestans in some countries, the illness remains as one of the most important neglected diseases and is now spreading into some non-endemic areas because of human migrations. $(15,16)$ Countries such as Australia, Canada, Japan, Spain, and the United States of America are the most affected

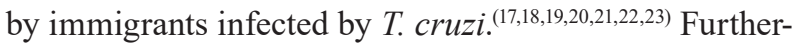
more, climatic and environmental changes may develop new behavioral patterns and adaptations of the triatomines, causing unexpected occurrences of transmission to be recorded. ${ }^{(24)}$ Oral transmission, for instance, has been causing new acute cases and deaths, especially in the North of Brazil and Venezuela..$^{(25,26,27)}$ An important factor of oral transmission is the proximity of humans to infected vectors. Therefore, vectors also represent a keyfactor for this kind of contamination. According to Dias et al., ${ }^{(28)}$ new epidemiological situations have been observed 
in the last years. T. infestans has been eliminated in large geographic areas but remains infesting natural and artificial ecotopes in the Chaco region, especially in Argentina, ${ }^{(29)}$ while a similar situation can be observed in northern South and Central America regarding R. prolixus..$^{(9)}$ Additionally, the invasion of houses by T. tibiamaculata (Pinto, 1926) in Salvador (Bahia, Brazil) also stresses the importance of continuously monitoring the vectors. ${ }^{(30)}$ In conclusion, understanding the biology and ecology of the triatomines and their associations with humans is crucial to avoid new cases of Chagas disease. ${ }^{(31,32,33,34)}$

The objective of this review is to summarise the new species described after 1979, when Lent \& Wygodzinsky ${ }^{(1)}$ published the most complete review about the Triatominae subfamily. In this review we contextualise the new vector species regarding their ecological characteristics, epidemiologic importance, and the new obstacles they pose to the monitoring and control of Chagas disease around the world.

\section{Triatominae until 1979}

Triatomines have been known since the 18th century, when the first species, T. rubrofasciata (De Geer, 1773), first called "Cimex rubrofasciatus" (De Geer, 1773), was described in Indonesia. At that time, this tropicopolitan species was not recognised as a potential vector. Several other Triatominae species had been described before the discovery of the disease, such as T. infestans and Panstrongylus megistus (Burmeister, 1835); the latter being the first species to be shown as a vector in the endemic areas of the State of Minas Gerais, Brazil. However, 136 years passed after the description of $T$. rubrofasciata until the disease was described by Carlos Chagas. Despite the difficulties in proving the existence of the new disease in a region plagued by a great number of other illnesses, the Brazilian physicist Carlos Chagas described not only its symptoms and the clinical aspects, but also the sensitive agents, the hosts, the etiologic agent, and the vectors. ${ }^{(11,35,36)}$

The great majority of the bugs belonging to this subfamily, such as Cavernicola lenti Barrett \& Arias, 1985, C. pilosa Barber, 1937, Psammolestes coreodes Bergroth, 1911, P. tertius Lent \& Jurberg, 1965, Parabelminus carioca Lent, 1943, and P. уитириси Lent \& Wygodzinsky, 1979 , among many others, can only be found in their natural sylvatic environments. ${ }^{(1)}$ Many other species are able to eventually invade domiciles, mainly attracted by light, ${ }^{(37)}$ but just a few species are recognised as major threats to public health, like T. brasiliensis brasiliensis Neiva, 1911, T. infestans, T. pseudomaculata Corrêa \& Espínola, 1964, T. sordida (Stål, 1859), P. megistus, R. prolixus, R. ecuadoriensis Lent \& Leon, 1958, and T. dimidiata. ${ }^{(38)}$ Thus, the knowledge about the process of adaptation of the triatomines to the human dwellings is fundamental to design and propose effective vector control strategies. ${ }^{(39)}$

After the discovery of the disease, Neiva ${ }^{(40)}$ was one of the first scientists interested in understanding the vectorial capacity of the distinct species, and Lent \& Wygodzinsk ${ }^{(1)}$ have published the most complete review of the triatomines so far.

\section{Target species}

As previously mentioned, despite the achievements in controlling populations of the most important anthropophilic vector, several native species must be monitored, reaffirming the need for constant technical activities to check for invasions or domiciliation. This group of species includes: T. brasiliensis, $P$. geniculatus (Latreille, 1811), R. brethesi Matta, 1919, R. prolixus, $R$. nasutus Stål, 1859, $R$. neglectus Lent, 1954, T. dimidiata, T. maculata (Erichson, 1848), T. rubrovaria (Blanchard, 1843), T. sanguisuga (Leconte, 1855), and T. vitticeps (Stål, 1859) according to Costa \& Lorenzo. ${ }^{(33)}$

Triatoma rubrofasciata represents a particular case. This species exhibits domestic habits and is found predominantly in the New World, mainly in Latin America. Although it has only been reported in very limited regions of Brazil in the past 30 years, there have been occurrences of the species feeding on humans in Southeast Asia, where severe bite reactions, sometimes leading to anaphylactic shock, have been recorded. Reports of this species in Asia have increased significantly in the last five years. ${ }^{(41,42)}$ Recently, this species has also been recorded in China. ${ }^{(43,44)}$ Thus, its epidemiological importance is a matter of concern. ${ }^{(45)}$ The trend to increased domesticity of this species represents what we could expect from other species which are not closely monitored because they are not currently regarded as target species.

\section{Native vectors}

More than ten different species of triatomines have been found in the United States of America, with the highest diversity and density in the states of Texas, New Mexico, and Arizona. ${ }^{(46)}$ In Texas and other Southern states of the USA, the most collected species were $T$. sanguisuga and T. gerstaeckeri (Stål, 1859). These native vectors are occasionally found in households, but usually without robust signs of colonisation..$^{(47)}$

Rhodnius prolixus is the main Chagas disease vector in Venezuela, Colombia, and certain areas of Central America, where it can build up large colonies inside human domiciles. ${ }^{(48)}$ The other two main species implicated in Chagas disease eco-epidemiology in Central American countries are $T$. dimidiata and $R$. pallescens Barber, 1932. ${ }^{(49)}$ The members of the T. phyllosoma complex (Meccus Stål, 1859 in some literature) are also found invading and colonising human domiciles in Mexico. ${ }^{(18)}$

The current scenario is quite challenging in Brazil, where there are 66 triatomine species recorded, of which 37 are native. Therefore, the country presents the highest diversity in this group of insects. ${ }^{(33,34,50,51,52,53,54)}$

It is also important to highlight that more than 20 triatomine species have already been recorded in the Brazilian Amazon Forest, ${ }_{(5,56,57,58,59,60)}$ which corresponds to roughly $40 \%$ of the Brazilian territory and is one of the richest areas on the planet in terms of biodiversity. ${ }^{(61)}$ Some of the difficulties found in this region are: (i) the lack of data on the habitats of the newly described triatomines; (ii) triatomines that may be losing their natural habitats because of environmental changes; (iii) the very probable existence of undescribed spe- 
cies; and (iv) the lack of detailed studies on the species already recorded in the area. These factors impede an accurate estimate of the risk of dissemination of the Chagas disease in the Amazon. ${ }^{(62)}$

\section{Triatominae after 1979}

Since the publication of the remarkable Lent \& Wygodzinsky ${ }^{(1)}$ monograph in 1979, describing and illustrating 111 triatomines, 46 species and one subspecies have been described as new or revalidated. They were included in 12 of the 19 genera of the subfamily, which now represent 157 known species (154 living species and three fossils) from 15 countries, ${ }^{(52,53,63,64,65,66,67,68)}$ plus a subspecies ${ }^{(69)}$ (Table). Out of those 47 triatomines, 17 are from Brazil, followed by Mexico and Colombia, each with four species (post-1979). In the remainder 12 countries, 22 triatomines have been recorded, and the numbers varied from one to two in each one (Table, Figure).

Twenty-one of the 47 new or revalidated taxa (post1979) belong to the genus Triatoma Laporte, 1832, nine to Rhodnius Stål, 1859, and four to Panstrongylus Berg, 1879 (Table). The fact that 34 of the 47 newly validated triatomines belong to the three genera with the highest medical importance is noteworthy. However, among them, only five show clues of house invasion or domiciliation. The three first triatomines, T. juazeirensis Costa \& Felix, 2007, T. b. macromelasoma Galvão, 1956, and T. sherlocki Papa et al., 2002, are included in the T. brasiliensis species complex. ${ }^{(69,70,71)}$ Triatoma bahiensis Sherlock \& Serafim, 1967 and T. melanica Neiva \& Lent, 1941 were also included in that species complex and eventually invade houses, but have not exhibited signals of domiciliation yet. ${ }^{(37,71,72,73)}$ The fourth triatomine, $T$. rosai Alevi et al. is able to colonise a great diversity of natural ecotopes and is also found infesting domiciliary and peridomiciliary areas in Argentina, as well as in Bolívia and Paraguay. ${ }^{(68,74)}$ The fifth species, T. huehuetenanguensis was found naturally infected by $T$. cruzi in domestic ecotopes. ${ }^{(65)}$ The two exceptions of triatomines (Table) collected in the intradomicile without clues of domiciliation or frequent invasion are the Belminus species, B. corredori and B. ferroae, known to be sylvatic species. Both were captured in Colombia, inside dwellings. ${ }^{(75,76)}$ Since then, no further report on these species in domiciliary ecotopes have been made. Therefore, it is highly probable that those specimens invaded the houses when they were captured.

In this sense, the great majority, 42 of the 47 triatomines listed post-1979, do not appear to be capable of changing the epidemiology or the currently known $T$. cruzi transmission profiles to human populations (Table).

\section{Valid species and the importance of integrative analysis}

Rhodnius amazonicus Almeida, Santos \& Sposina, 1973 and R. zeledoni Jurberg Rocha \& Galvão, 2009 are triatomines of rare occurrence, recorded in the north and northeastern Brazil. ${ }^{(77,78)}$ However, they still need to have their taxonomic status confirmed molecularly. ${ }^{(79)}$ It is applied also to a Bolivian species - T. boliviana Martinez et al., 2007, related to T. nigromaculata (Stål, 1859). ${ }^{(80)}$ The confirmation of the specific status of species of the genus
Rhodnius by means of molecular data and experimental crossings proved to be extremely important in the face of the events of cryptic speciation and phenotypic plasticity of the species. ${ }^{(66,79)}$ Rhodnius taquarussuensis Rosa et al., 2017, for example, was recently synonymised with $R$. neglectus after applying molecular analyses. ${ }^{(66)} T$. rosai is closely related to $T$. sordida and was characterised based on integrative taxonomy which is crucial for describing and characterising new taxa. Unfortunately, at times, the integrative taxonomy cannot be carried out as is the case of the recently described species $R$. micki Zhao, Galvão $\&$ Cai, 2021. Its characterisation was based on morphological and geometric morphometrics analysis using specimens from a collection. ${ }^{(81)}$

In regard to the Triatominae, phenotypic variability has been observed in several taxa, so the multidisciplinary approach is mandatory to avoid misinterpretation of the intra specific variations. Natural hybridisation, which generates phenotypic variation, has been recently explored in the triatomine group and could be more common than already recorded. ${ }^{(22,83,84,85)}$ For example, in a natural hybrid zone identified in the State of Pernambuco, Brazil, 13 phenotypes (nine of them intermediate between $T$. b. brasiliensis and T. juazeirensis) were revealed for T. brasiliensis complex, based on molecular analysis. ${ }^{\left({ }^{(8)}\right.}$ On the other hand, the possibility of the existence of new species due to the detection of genetic variations in taxa that are now considered a single taxon, such as Mepraia Mazza, Gajardo \& Jörg, 1940;(87) R. pallescens Barber, 1932;(88) T. patagonica Del Ponte, $1929 ;{ }^{(89)}$ T. costalimai Verano \& Galvão, $1958 ;{ }^{(90)}$ and $R$. ecuadoriensis, ${ }^{(91,92,93,94)}$ was demonstrated.

It is crucial to highlight that in the triatomine group the descriptions of new species in the T. brasiliensis, $T$. sordida, T. dimidiata, and Mepraia complexes, as well as in some Rhodnius species, were due to integrative analysis using morphological, isoenzymatic, chromosomal and molecular studies that detected population variations compatible with the existence of species and cryptic species. A detailed comprehensive review of these cases was presented by Monteiro et al. ${ }^{(95)}$

\section{Variety of ecotopes and the challenges of the control programs}

A notorious variety of ecotopes of the triatomines described or revalidated pos-1979 was recorded. The ecotopes are in accordance with the previous knowledge of the triatomine group as mentioned in Lent \& Wygodzinsky. ${ }^{(1)}$ For instance, most of the species of the Triatoma genus were recorded occupying rocky outcrops ecotopes, except for T. rosai related to distinct natural ecotopes. While Rhodnius species have as the primary habitat different species of palm trees, species of Panstrongylus genus are predominantly associated with burrows and tree cavities in their primary habitats. ${ }^{(32)}$ However, as above-mentioned, these three genera exhibit species with the ability to adapt to the anthropic environment - a process known as domiciliation. ${ }^{(39,96,97)}$

In addition to the domiciliary infestation, it is important to mention the vector control programs are not strongly supported by governmental institutions or are 


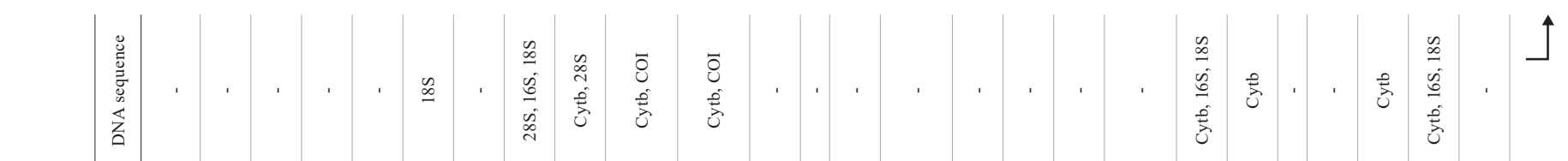

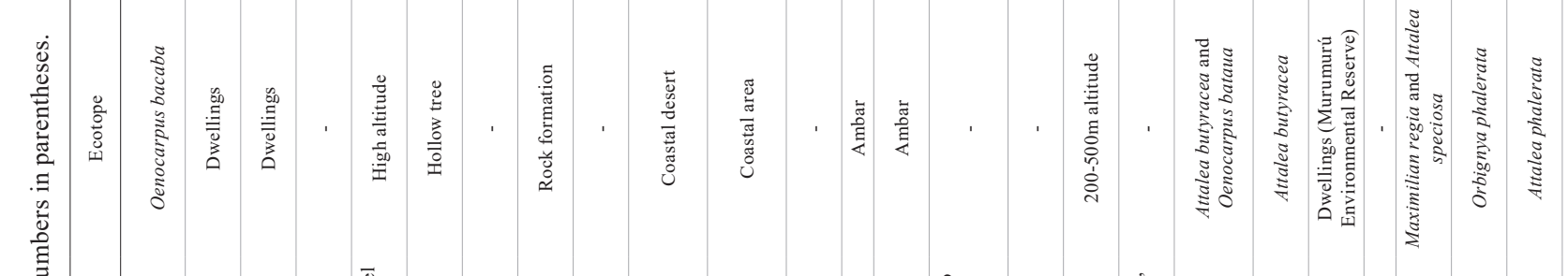

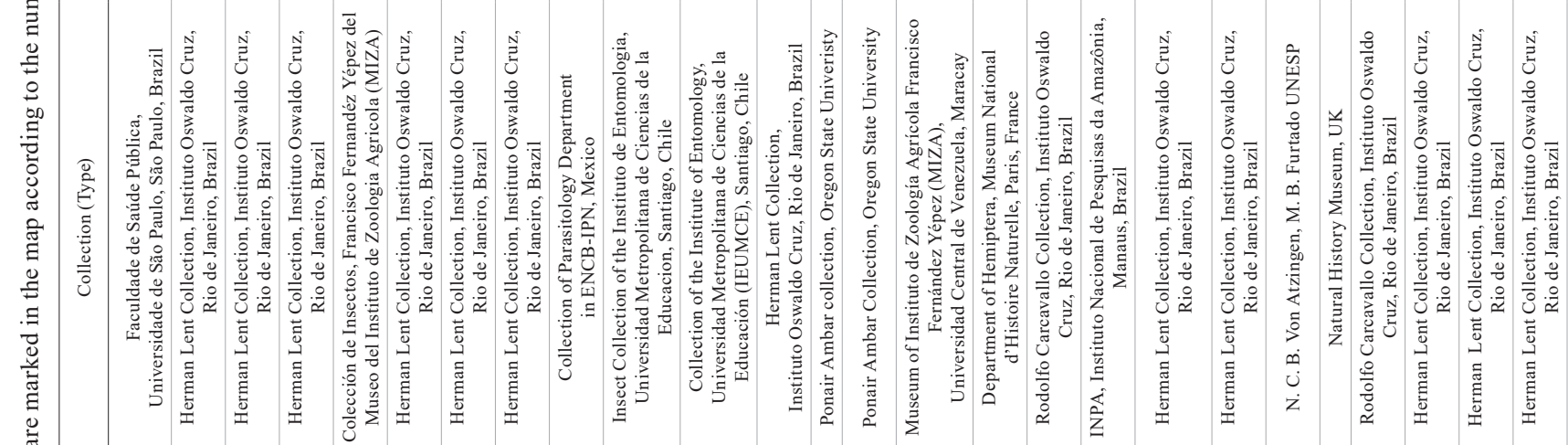

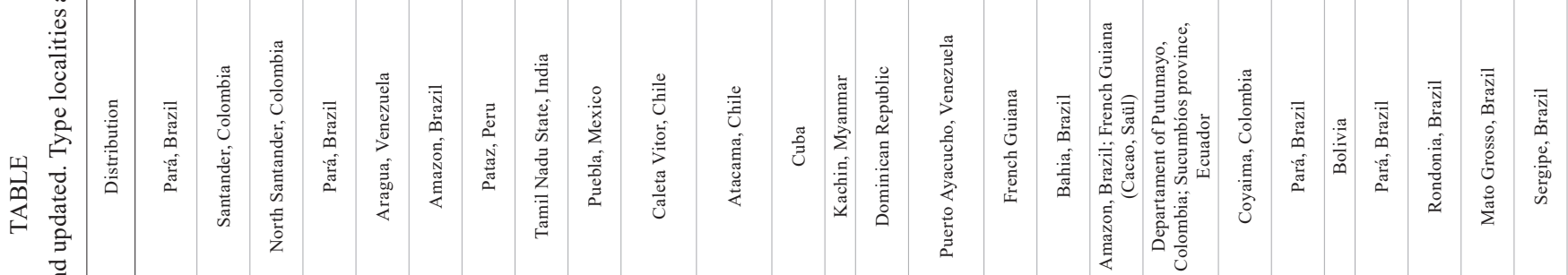

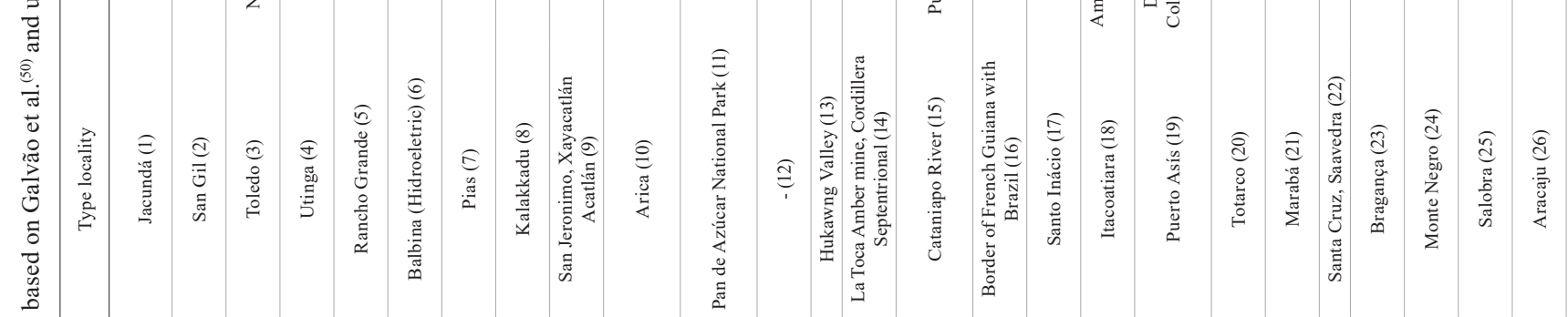

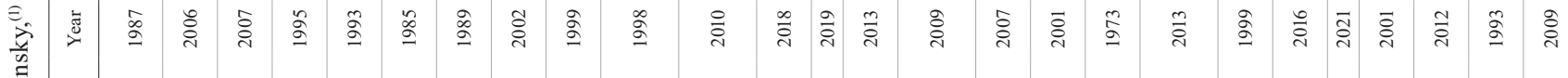

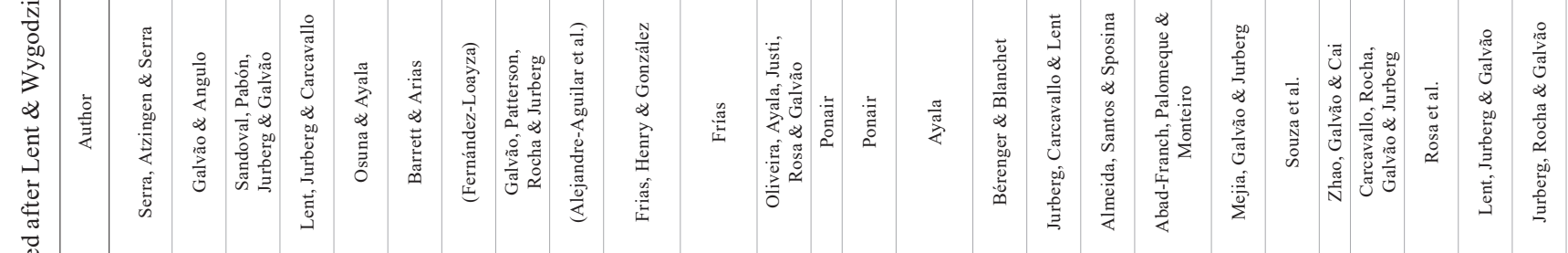

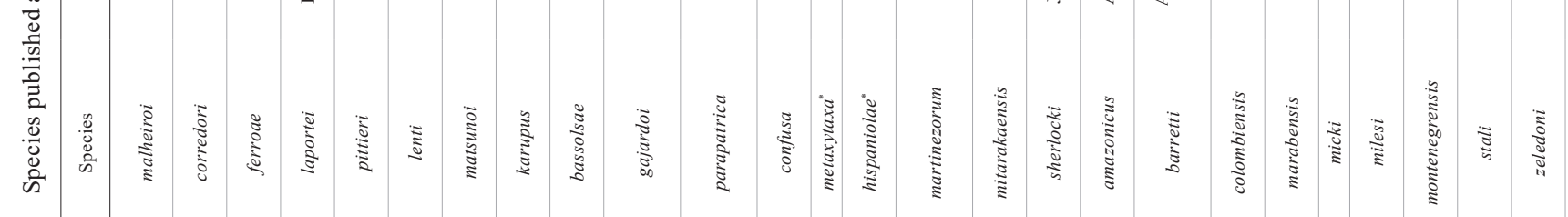

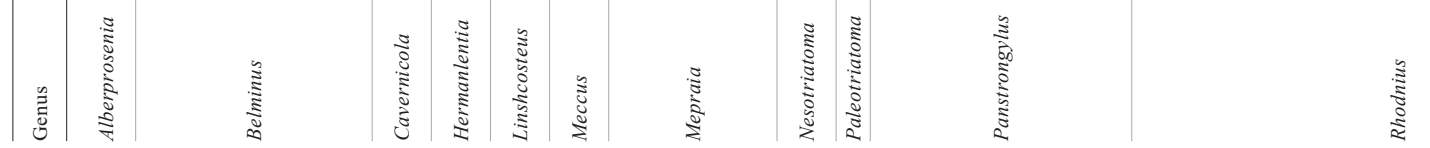




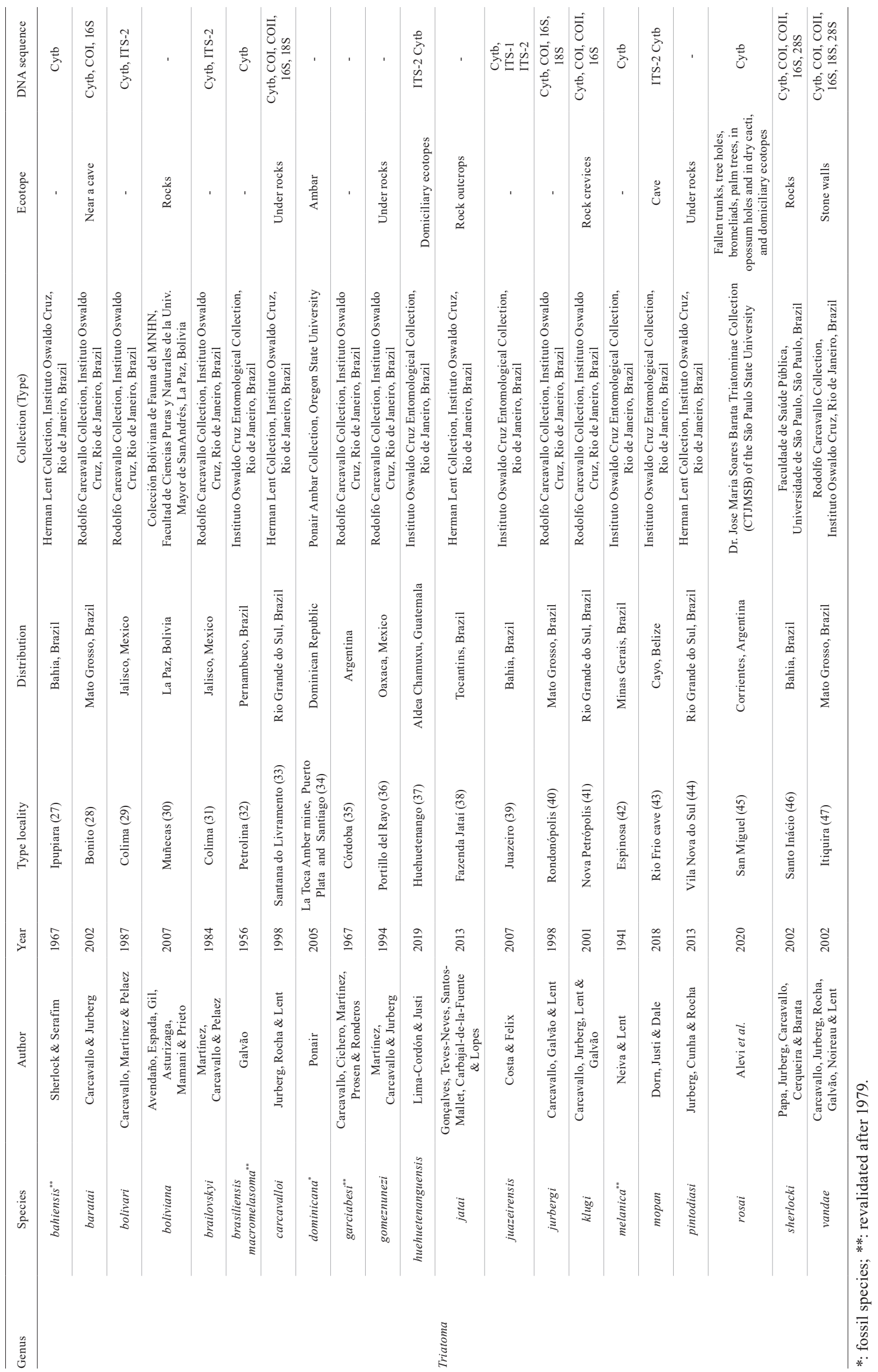



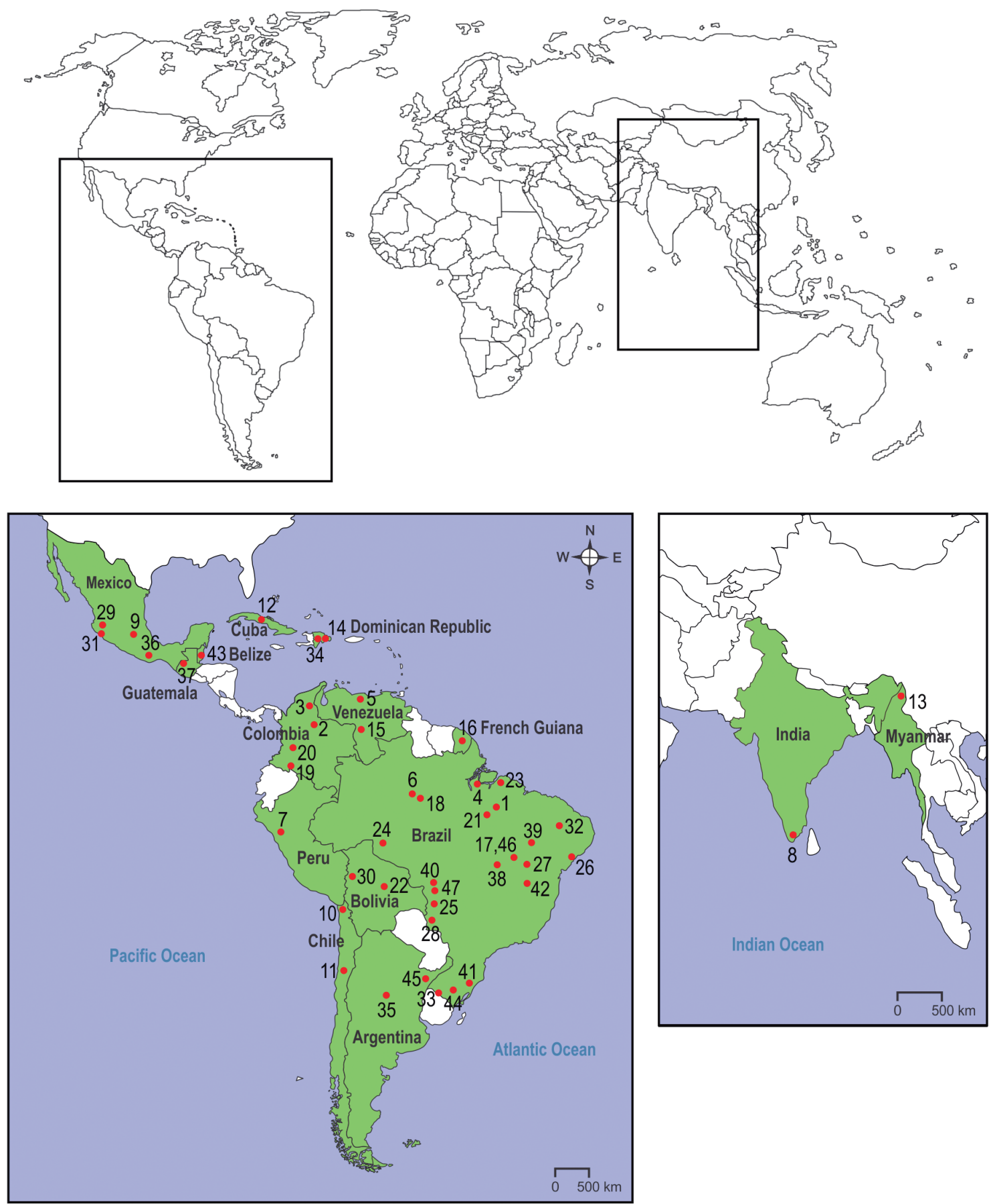

Distributional map of the 46 Triatominae species and one subspecies described or revalidated after Lent \& Wygodzinsky, ${ }^{(1)}$ from 15 countries and three continents. Numbers represent the type localities listed in the table.

almost inexistent in some of the endemic countries. ${ }^{(98)}$ Another major obstacle is the interruption or reduction of T. cruzi transmission by native vectors. ${ }^{(99)}$ The precarious information system is also a barrier to a robust evaluation of the actual epidemiological scenario, mainly in Bolivia, Paraguay, and Mexico. ${ }^{(6)}$ In Brazil, a common problem is the lack of stable funds for vector control. Besides that, the focus to control Chagas disease is frequently weakened when other threats (e.g., dengue fever,
Zika, Chikungunya, and yellow fever, and leishmaniosis) take place. Vector control strategies must be designed to overcome some of these problems, such as the Integrated Vector Management (IVM) - a worldwide trend.(7)

Furthermore, there are difficulties in monitoring and controlling the vectors in hyperendemic areas like the Gran Chaco (Argentina) because of the high infestation indices. In these areas, the use of insecticides is extremely frequent, and resistance has already been de- 
tected in T. infestans. ${ }^{(100)}$ More recently, localities highly infested by infected $T$. brasiliensis were also studied by Lillioso et al. ${ }^{(101)}$ raising new issues for the Northeast region, Brazil, since this species is recorded in five Brazilian states. ${ }^{(70)}$ Finally, even though there are no domiciliated species in the United States of America, an increasing number of autochthonous cases of Chagas disease has been noted, which is a matter of concern to the health authorities in that country. ${ }^{(102,103)}$

Besides the new vectorial problems, it is important to mention the threats imposed by (i) the lack of maintenance of national programs using new technologies to monitor and prevent Chagas disease; ${ }^{(38)}$ (ii) the climate change and human activities constantly changing the natural environment; and (iii) the new species of triatomines being described. This evolving scenario requires a constant monitoring activity in the endemic countries for Chagas disease, as well as comprehensive educational programs. It is now suggested that some triatomine species are able to adapt to new environmental conditions, invade new areas, ${ }^{(70)}$ and generate new phenotypes, which also poses new challenges and questions for the understanding of vector-parasite interactions and controlling of the disease, and the $T$. cruzi transmission. ${ }^{(86)}$

\section{In conclusion}

In conclusion, the 47 post-1979 triatomines described or revalidated do not seem to change the current epidemiological status of the Chagas disease, because most of them are strictly sylvatic (Table). In that list, there are only five exceptions, the first one is T. juazeirensis, ${ }^{(70,72,104)}$ which is very well-studied in the State of Bahia (Brazil) and frequently encountered inside houses and near forested areas; the second, also found in Bahia, is $T$. sherlocki, showing an incipient capacity for colonising domiciles. ${ }^{(105,106)}$ The third is $T . b$. macromelasoma, from Pernambuco State, where this vector is frequently found in the peridomicile however, eventually it can be found infesting the domiciles. ${ }^{(69,71)}$ The fourth one is $T$. rosai which occupies a great variety of ecotopes in several areas of Argentina, Bolivia and Paraguay ${ }^{(68,74)}$ and the fifth one is T. huehuetenanguensis, found naturally infected by $T$. cruzi in domestic ecotopes, being considered a potential important vector in Guatemala. ${ }^{(65)}$

Despite the evidence that the great majority of the post-1979 revalidated or new species of triatomines are not able to change the classical epidemiologic scenario of the T. cruzi transmission, a great effort must be devoted aiming to improve the knowledge of the recently described species. For instance, most of them lack a characterisation of their molecular profiles and even the phylogenetic relationships and detailed ecological studies. These gaps in the knowledge of a variety of species impair a more complete understanding of their evolutionary history as well as the possibility of a comparative analysis of the ecology of the Triatominae.

According to the literature, the reports of $\mathrm{WHO}^{(7)}$ and the profile of the triatomines listed in the Table, the main acknowledged vectors like $T$. infestans, $R$. prolixus, and $T$. dimidiata are going to continue to be the great threats of the T. cruzi transmission to human populations. Sev- eral other species presenting a more reduced geographical distribution are going to persist infesting dwellings in several countries such as T. brasiliensis in northeastern Brazil ${ }^{(70)}$ and P. geniculatus in Colômbia. ${ }^{(107)}$ In the face of the relative small epidemiologic importance of the majority of the 47 triatomines listed after Lent \& Wygodzinsky, ${ }^{(1)}$ and the significant achievements in terms of modern technologies such as: diagnosis of the diseases, clinical evaluations, precise tools for molecular identification of the vector species, and the T. cruzi discrete typing units (DTUs) characterisation, modeling triatomines distribution throughout algorithm processes, the monitoring of vectors, and the educational programs are still the main actions to keep human populations free of Chagas disease. ${ }^{(108)}$

\section{ACKNOWLEDGEMENTS}

To Dr Andrew Townsend Peterson, Biodiversity Center, Kansas University, USA, and Dr Felipe FF Moreira, Lab Entomological Biodiversity, IOC-Fiocruz, for their helpful comments; Angela Vasconcellos for the English language revision; Heloisa Diniz, Technical Support Department, for the table edition and map illustration; and the referees, for the detailed analysis of the manuscript and relevant suggestions.

\section{AUTHORS' CONTRIBUTION}

$\mathrm{JC}$ - Conceptualisation and writing of the first version; $\mathrm{CD}$ and $\mathrm{CG}$ - table content. All authors equally contributed to writing the versions, editing, and revising the text. The authors declare no conflict of interest concerning this manuscript.

\section{REFERENCES}

1. Lent H, Wygodzinsky P. Revision of the Triatominae (Hemiptera, Reduviidae), and their significance as vectors of Chagas disease. Bull Am Museum Nat Hist. 1979; 163(3): 123-520.

2. Stanaway JD, Roth G. The burden of Chagas disease estimates and challenges. Glob Heart. 2015; 10(3): 139-44.

3. Cordovez JM, Sanabria C. Environmental changes can produce shifts in Chagas disease infection risk. Environ Health Insights. 2014; 8(Suppl. 2): 43-8

4. Dias JCP, Cláudio LDG, Lima MM, Albajar-Viñas P, Silva RAE, Alves RV, et al. Changes in the paradigm of clinical and therapeutic management of Chagas' disease: progress and perspectives in the pursuit of comprehensive health. Epidemiol Serv Saúde Rev. 2016; 25(spe): 87-90.

5. WHO - World Health Organization. Chagas disease (American trypanosomiasis). Fact sheet No 340. Geneva: WHO; 2016.

6. Moncayo A, Silveira AC. Current epidemiological trends of Chagas disease in Latin America and future challenges: epidemiology, surveillance and health policy. Mem Inst Oswaldo Cruz. 2009; 104(Suppl. 1): 17-30.

7. WHO -World Health Organization. Handbook for integrated vector management. Geneva: WHO; 2013.

8. Dias JCP, Silveira AC, Schofield CJ. The impact of Chagas disease control in Latin America - A review. Mem Inst Oswaldo Cruz. 2002; 97(5): 603-12.

9. Hashimoto K, Schofield CJ. Elimination of Rhodnius prolixus in Central America. Parasit Vectors. 2012; 5: 45.

10. Peterson JK, Hashimoto K, Yoshioka K, Dorn PL, Gottdenker NL, Caranci A, et al. Chagas disease in Central America: recent findings and current challenges in vector ecology and control. Curr Trop Med Rep. 2019; 6(Suppl. 1): 76-91. 
11. Chagas C. Nova tripanozomiaze humana. Estudos sobre a morfolojia e o ciclo evolutivo do Schizotrypanum cruzi n. gen., n. sp., ajente etiolojico de nova entidade morbida do homem. Mem Inst Oswaldo Cruz. 1909; 1(2): 159-218.

12. Dias JP, Bastos C, Araújo E, Mascarenhas AV, Netto EM, Grassi F, et al. Acute Chagas disease outbreak associated with oral transmission. Rev Soc Bras Med Trop. 2008; 41(3): 296-300.

13. Castro E. Chagas' disease: lessons from routine donation testing. Transfus Med. 2009; 19(1): 16-23.

14. Kransdorf EP, Zakowski PC, Kobashigawa JA. Chagas disease in solid organ and heart transplantation. Curr Opin Infect Dis. 2014; 27(5): 418-24.

15. Guhl F, Jaramillo C, Vallejo GA, A-Arroyo FC, Aufderheide A. Chagas disease and human migration. Mem Inst Oswaldo Cruz. 2000; 95(4): 553-5.

16. Coura JR, Vĩnas PA. Chagas disease: a new worldwide challenge. Nature. 2010; 465(Suppl.): S6-7.

17. Schmunis GA. Epidemiology of Chagas disease in non-endemic countries: the role of international migration. Mem Inst Oswaldo Cruz. 2007; 102(Suppl. 1): 75-85.

18. Patterson JS, Guhl F. Geographical distribution of Chagas disease. Am Trypanos. 2010; 83-114.

19. Antinori S, Galimberti L, Bianco R, Grande R, Galli M, Corbellino M. Chagas disease in Europe: a review for the internist in the globalized world. Eur J Intern Med. 2017; 43: 6-15.

20. Monge-Maillo B, López-Vélez R. Challenges in the management of Chagas disease in Latin-American migrants in Europe. Clin Microbiol Infect. 2017; 23(5): 290-5.

21. Romay-Barja M, Boquete T, Martinez O, González M, ÁlvarezDel Arco D, Benito A, et al. Chagas screening and treatment among Bolivians living in Madrid, Spain: the need for an official protocol. PLoS One. 2019; 14(3): e0213577.

22. Romay-Barja M, Boquete T, Martinez O, Benito A, BlascoHernández T. Factors associated with Chagas screening among immigrants from an endemic country in Madrid, Spain. PLoS One. 2020; 15(3): e0230120.

23. Gómez i Prat J, Peremiquel-Trillas P, Guiu IC, Mendivelso JC, Choque E, Santos JJ, et al. Comparative evaluation of community interventions for the immigrant population of Latin American origin at risk for Chagas disease in the city of Barcelona. PLoS One. 2020; 15(7): e0235466.

24. Coura JR, Junqueira ACV. Risks of endemicity, morbidity and perspectives regarding the control of Chagas disease in the Amazon Region. Mem Inst Oswaldo Cruz. 2012; 107(2): 145-54.

25. Coura JR. The main sceneries of Chagas disease transmission. The vectors, blood and oral transmissions - A comprehensive review. Mem Inst Oswaldo Cruz. 2015; 110(3): 277-82.

26. Souza-Lima RC, Barbosa MGV, Coura JR, Arcanjo ARL, Nascimento AS, Ferreira JMBB, et al. Outbreak of acute Chagas disease in the Rio Negro region, Brazilian Amazon. Rev Soc Bras Med Trop. 2013; 46(4): 510-4.

27. Alarcón de Noya B, Díaz-Bello Z, Colmenares C, Ruiz-Guevara R, Mauriello L, Muñoz-Calderón A, et al. Update on oral Chagas disease outbreaks in Venezuela: epidemiological, clinical and diagnostic approaches. Mem Inst Oswaldo Cruz. 2015; 110(3): 377-86.

28. Dias JCP, Coura JR, Yasuda MAS. The present situation, challenges, and perspectives regarding the production and utilization of effective drugs against human Chagas disease. Rev Soc Bras Med Trop. 2014; 47(1): 123-5.
29. Enriquez GF, Cecere MC, Alvarado-Otegui JA, Alvedro A, Gaspe MS, Laiño MA, et al. Improved detection of house infestations with triatomines using sticky traps: a paired-comparison trial in the Argentine Chaco. Parasit Vectors. 2020; 13: 26.

30. Dias-Lima AG, Sherlock IA. Sylvatic vectors invading houses and the risk of emergence of cases of Chagas disease in Salvador, State of Bahia, Northeast Brazil. Mem Inst Oswaldo Cruz. 2000; 95(5): 611-3.

31. Costa J. The synanthropic process of Chagas disease vectors in Brazil, with special attention to Triatoma brasiliensis Neiva, 1911 (Hemiptera, Reduviidae, Triatominae) population, genetical, ecological, and epidemiological aspects. Mem Inst Oswaldo Cruz. 1999; 94(Suppl. 1): 239-41.

32. Gaunt M, Miles M. The ecotopes and evolution of triatomine bugs (Triatominae) and their associated trypanosomes. Mem Inst Oswaldo Cruz. 2000; 95(4): 557-65.

33. Costa J, Lorenzo M. Biology, diversity and strategies for the monitoring and control of triatomines - Chagas disease vectors. Mem Inst Oswaldo Cruz. 2009; 104(Suppl. 1): 46-51.

34. Galvão C, Justi SA. The evolutionary origin of diversity in Chagas disease vectors. Trends Parasitol. 2015; 33(1): 42-52.

35. Kropf SP, Sá MR. The discovery of Trypanosoma cruzi and Chagas disease (1908-1909): tropical medicine in Brazil. Hist Cienc Saude-Manguinhos. 2009; 16(Suppl. 1): 13-34.

36. Steverding D. The history of Chagas disease. Parasit Vectors. 2014; 7: 317 .

37. Costa J, Almeida CE, Dotson EM, Lins A, Vinhaes M, Silveira AC, et al. The epidemiologic importance of Triatoma brasiliensis as a Chagas disease vector in Brazil: a revision of domiciliary captures during 1993-1999. Mem Inst Oswaldo Cruz. 2003; 98(4): 443-9.

38. Silveira AC, Vinhaes MC. Elimination of vector-borne transmission of Chagas disease. Mem Inst Oswaldo Cruz. 1999(Suppl. 1); 94: 405-11.

39. Waleckx E, Gourbière S, Dumonteil E. Intrusive versus domiciliated triatomines and the challenge of adapting vector control practices against Chagas disease. Mem Inst Oswaldo Cruz. 2015; 110(3): 324-38.

40. Neiva A. Contribuição para o estudo dos hematophagos brasileiros e descrição de uma nova espécie de Triatoma. Bras Med. 1911; 25: 461-2.

41. Dujardin JP, Thi KP, Xuan LT, Panzera F, Pita S, Schofield CJ. Epidemiological status of kissing-bugs in South East Asia: a preliminary assessment. Acta Trop. 2015; 151: 142-9.

42. Hieu HV, Do LT, Pita S, Ha H, Khoa PT, Tuan PA, et al. Biological attributes of the kissing bug Triatoma rubrofasciata from Vietnam. Parasit Vectors. 2019; 12: 585.

43. Liu Q, Wu F, Shi Y, Lu W, Xie H, Guo Y, et al. Distribution of triatomines, the vectors of Chagas disease - Southern China, 20162018. China CDC Weekly. 2020; 2: 629-33.

44. Shi Y, Wei Y, Feng X, Liu J, Jiang Z, Ou F, et al. Distribution, genetic characteristics and public health implications of Triatoma rubrofasciata, the vector of Chagas disease in Guangxi, China. Parasit Vectors. 2020; 13(1): 33.

45. Dujardin J-P, Lam TX, Khoa PT, Schofield CJ. The rising importance of Triatoma rubrofasciata. Mem Inst Oswaldo Cruz. 2015; 110(3): 319-23.

46. Sarkar S, Strutz SE, Frank DM, Rivaldi CL, Sissel B, SánchezCordero V. Chagas disease risk in Texas. PLoS Negl Trop Dis. 2010: e836. 
47. Curtis-Robles R, Hamer SA, Lane S, Levy MZ, Hamer GL. Bionomics and spatial distribution of triatomine vectors of Trypanosoma cruzi in Texas and other Southern states, USA. Am J Trop Med Hyg. 2018; 98(1): 113-21.

48. Guhl F. Chagas disease in Andean countries. Mem Inst Oswaldo Cruz. 2007; 102(Suppl. 1): 29-37.

49. Ponce C. Current situation of Chagas disease in Central America. Mem Inst Oswaldo Cruz. 2007; 102(Suppl. 1): 41-4.

50. Galvão C, Carcavallo R, Rocha DDS, Jurberg J. A checklist of the current valid species of the subfamily Triatominae Jeannel, 1919 (Hemiptera, Reduviidae) and their geographical distribution, with nomenclatural and taxonomic notes. Zootaxa. 2003; 202(1): 1-36.

51. Gurgel-Gonçalves R, Galvão C, Costa J, Peterson AT. Geographic distribution of Chagas disease vectors in Brazil based on ecological niche modeling. J Trop Med. 2012; 705326.

52. Justi SA, Russo CAM, Mallet JRS, Obara MT, Galvão C. Molecular phylogeny of Triatomini (Hemiptera: Reduviidae: Triatominae). Parasit Vectors. 2014; 7: 149.

53. Galvão C. Vetores da doença de Chagas no Brasil. Guias e manuais de identificação. Curitiba: Sociedade Brasileira de Zoologia; 2014.

54. Souza ES, von Atzingen NCB, Furtado MB, Oliveira J, Nascimento JD, Vendrami DP, et al. Description of Rhodnius marabaensis sp. n. (Hemiptera, Reduviidade, Triatominae) from Pará State, Brazil. Zookeys. 2016; 621: 45-62.

55. Coura JR, Junqueira ACV, Fernandes O, Valente SAS, Miles MA. Emerging Chagas disease in Amazonian Brazil. Trends Parasitol. 2002; 18(4): 171-6.

56. Meneguetti DUO, Trevisan O, Rosa RM, Camargo LMA. First report of Eratyrus mucronatus, Stal, 1859, (Hemiptera, Reduviidae, Triatominae) in the State of Rondônia, Brazil. Rev Soc Bras Med Trop. 2011; 44(4): 511-2.

57. Terassini FA, Stefanello C, Camargo LMA, Meneguetti DUO First report of Panstrongylus lignarius, Walker, 1873 (Hemiptera, Reduviidae, Triatominae), in the State of Rondônia, Brazil. Rev Soc Bras Med Trop. 2017; 50(4): 547-9.

58. Castro MALR, Castro GVS, de Souza JL, de Souza CR, Ramos LJ, Oliveira J, et al. First report of Panstrongylus megistus (Hemiptera, Reduviidae, Triatominae) in the states of Acre and Rondônia, Amazon, Brazil. Acta Trop. 2018; 182: 158-60.

59. Oliveira AS, Ribeiro MAL, Castro GVS, Brilhante NA, Camargo LMA, Meneguetti DUO. Confirmation of the occurrence of Panstrongylus rufotuberculatus (Champion, 1899) in the State of Acre, Western Amazon. Rev Soc Bras Med Trop. 2019; 52: e20180388

60. Madeira FP, Jesus AC, Moraes MHA, Oliveira AS, Oliveira J, Melxhior LAK, et al. Doença de Chagas: conceitos básicos de uma enfermidade negligenciada e seus vetores na Amazônia ocidental. In J Oliveira, KCC Alevi, LMA Camargo, DUO Meneguetti, orgs. Atualidades em medicina tropical no Brasil: vetores. Rio Branco: Stricto Sensu; 2020. p. 49-71.

61. Malhi Y, Roberts JT, Betts RA, Killeen TJ, Li W, Nobre CA. Climate change, deforestation, and the fate of the Amazon. Science. 2008; 319(5860): 169-72.

62. Briceño-León R. Chagas disease and globalization of the Amazon. Cad Saude Publica. 2007; 23(Suppl. 1): 33-40.

63. Dorn PL, Justi SA, Dale C, Stevens L, Galvão C, Lima-Cordón R, et al. Description of Triatoma mopan sp. n. from a cave in Belize (Hemiptera, Reduviidae, Triatominae). Zookeys. 2018; 775: 69-95.

64. Oliveira J, Ayala JM, Justi SA, Rosa JA, Galvão C. Description of a new species of Nesotriatoma Usinger, 1944 from Cuba and re- validation of synonymy between Nesotriatoma bruneri (Usinger, 1944) and $N$. flavida (Neiva, 1911) (Hemiptera, Reduviidae, Triatominae). J Vector Ecol. 2018; 43(1): 148-57.

65. Lima-Cordón RA, Monroy MC, Stevens L, Rodas A, Rodas GA, Dorn PL, et al. Description of Triatoma huehuetenanguensis sp. n., a potential Chagas disease vector (Hemiptera, Reduviidae, Triatominae). Zookeys. 2019; 820: 51-70.

66. Nascimento JD, Rosa JA, Salgado-Roa FC, Hernández C, Pardo-Diaz C, Alevi KCC, et al. Taxonomical over splitting in the Rhodnius prolixus (Insecta: Hemiptera: Reduviidae) clade: are $R$. taquarussuensis (da Rosa et al., 2017) and R. neglectus (Lent, 1954) the same species? PLoS One. 2019; 14(2): e0211285.

67. Poinar Jr G. A primitive triatomine bug, Paleotriatoma metaxytaxa gen. et sp. nov. (Hemiptera: Reduviidae: Triatominae), in mid-Cretaceous amber from northern Myanmar. Cretac Res. 2019; 93(1): 90-7.

68. Alevi KCC, de Oliveira J, Garcia ACC, Cristal DC, Delgado LMG, de Freitas Bittinelli I, et al. Triatoma rosai sp. nov. (Hemiptera, Triatominae): a new species of Argentinian Chagas disease vector described based on integrative taxonomy. Insects. 2020; 11(12): 830.

69. Costa J, Correia NC, Neiva VL, Gonçalves TCM, Felix M. Revalidation and redescription of Triatoma brasiliensis macromelasoma Galvão, 1956 and an identification key for the Triatoma brasiliensis complex (Hemiptera: Reduviidae: Triatominae). Mem Inst Oswaldo Cruz. 2013; 108(6): 785-9.

70. Costa J, Dornak LL, Almeida CE, Peterson AT. Triatoma brasiliensis species complex at present and under scenarios of future climate conditions. Parasit Vectors. 2014; 7: 238.

71. Dale C, Almeida CE, Mendonça VJ, Oliveira J, Rosa JA, Galvão $\mathrm{C}$, et al. An updated and illustrated dichotomous key for the Chagas disease vectors of Triatoma brasiliensis species complex and their epidemiologic importance. Zookeys. 2018; 11: 33-43.

72. Costa J, Almeida JR, Britto C, Duarte R, Marchon-Silva V, Pacheco R. Ecotopes, natural infection and trophic resources of Triatoma brasiliensis (Hemiptera, Reduviidae, Triatominae). Mem Inst Oswaldo Cruz. 1998; 93(1): 7-13.

73. Costa J, Argolo AM, Felix M. Redescription of Triatoma melanica Neiva \& Lent, 1941, new status (Hemiptera: Reduviidae: Triatominae). Zootaxa. 2006; 1385: 47-58.

74. Panzera F, Pita S, Nattero J, Panzera Y, Galvão C, Chavez T, et al. Cryptic speciation in the Triatoma sordida subcomplex (Hemiptera, Reduviidae) revealed by chromosomal markers. Parasit Vectors. 2015; 8: 495

75. Galvão C, Agulo VM. Belminus corredori, a new species of Bolboderini (Hemiptera: Reduviidae: Triatominae) from Santander, Colombia. Zootaxa. 2006; 1241: 61-8.

76. Sandoval CM, Pabon E, Jurberg J, Galvão C. Belminus ferroae n.sp. from the Colombian north-east, with a key to the species of the genus (Hemiptera: Reduviidae: Triatominae). Zootaxa. 2007; 1443: 55-64.

77. Jurberg J, Rocha DS, Galvão C. Rhodnius zeledoni sp. nov. afim de Rhodnius paraensis Sherlock, Guitton \& Miles, 1977 (Hemiptera, Reduviidae, Triatominae). Biota Neotrop. 2009; 9(1): 123-8.

78. Rosa JA, Souza ES, Costa Teixeira A, Barbosa RR, Souza AJ, Belintani T, et al. Third record of Rhodnius amazonicus and comparative study with $R$. pictipes (Hemiptera, Reduviidae, Triatominae). Acta Trop. 2017; 176: 364-72.

79. Abad-Franch F, Pavan MG, Jaramillo-O N, Palomeque FS, Dale C, Chaverra D, et al. Rhodnius barretti, a new species of Triatominae (Hemiptera: Reduviidae) from western Amazonia. Mem Inst Oswaldo Cruz. 2013; 108(Suppl. 1): 92-9. 
80. Carrasco EA, Rondon OP, Otalora-Luna F. Are Triatoma nigromaculata (Stål 1859) and Triatoma boliviana (Martínez Avendaño, Chávez Espada, Sossa Gil, Aranda Asturizaga, Vargas Mamani \& Vidaurre Prieto, 2007) (Hemiptera, Reduviidae, Triatominae) synonymous species? Saber Univ Oriente. 2018; 30: 523-5.

81. Zhao Y, Galvão C, Cai W. Rhodnius micki, a new species of Triatominae (Hemiptera, Reduviidae) from Bolivia. Zookeys. 2021; 1012: 71-93.

82. Costa J, Peterson AT, Dujardin JP. Morphological evidence suggests homoploid hybridization as a possible mode of speciation in the Triatominae (Hemiptera, Heteroptera, Reduviidae). Infect Genet Evol. 2009; 9(2): 263-70.

83. Dujardin JP, Costa J, Bustamante D, Jaramillo N, Catalá SS. Deciphering morphology in Triatominae: the evolutionary signals. Acta Trop. 2009; 110(2-3): 101-11.

84. Martínez-Hernández F, Martínez-Ibarra JA, Catalá S, Villalobos G, De la Torre P, Laclette JP, et al. Natural crossbreeding between sympatric species of the Phyllosoma complex (Insecta: Hemiptera: Reduviidae) indicates the existence of only one species with morphologic and genetic variations. Am J Trop Med Hyg. 2010; 82(1): 74-82.

85. Antunes CA, Paschoaletto-Dias L, Guimarães GA, Oliveira J, Rosa JA, Almeida CE, et al. Sexual choice in males of the Triatoma brasiliensis complex: a matter of maintenance of the species or genetic variability? The Open Parasitol J. 2020; 8: 1-9.

86. Costa J, Bargues MD, Neiva VL, Lawrence G, Gumiel M, Oliveira $\mathrm{G}$, et al. Phenotypic variability confirmed by nuclear ribosomal DNA suggests a possible natural hybrid zone of Triatoma brasiliensis species complex. Infect Genet Evol. 2016; 37: 77-87.

87. Campos-Soto R, Díaz-Campusano G, Rives-Blanchard N, Cianferoni F, Torres-Pérez F. Biogeographic origin and phylogenetic relationships of Mepraia (Hemiptera, Reduviidae) on islands of northern Chile. PLoS One. 2020; 15(6): e0234056.

88. Kieran TJ, Bayona-Vásquez NJ, Varian CP, Saldaña A, Samudio F, Calzada JE, et al. Population genetics of two chromatic morphs of the Chagas disease vector Rhodnius pallescens Barber, 1932 in Panamá. Infect Genet Evol. 2020; 84: 104369.

89. Nattero J, Pita S, Calleros L, Crocco L, Panzera Y, Rodríguez CS, et al. Morphological and genetic differentiation within the southernmost vector of Chagas disease: Triatoma patagonica (Hemiptera - Reduviidae). PLoS One. 2016; 11: e0168853.

90. Vendrami DP, Ceretti-Jr W, Obara MT, Mendonça VJ, Fonseca EOL, Medeiros-Sousa AR, et al. Phenotypic and genetic variation of Triatoma costalimai (Hemiptera: Reduviidae). Rev Soc Bras Med Trop. 2021; 54: e00282020.

91. Pita S, Panzera F, Ferrandis I, Galvão C, Gómez-Palacio A, Panzera Y. Chromosomal divergence and evolutionary inferences in Rhodniini based on the chromosomal location of ribosomal genes. Mem Inst Oswaldo Cruz. 2013; 108(3): 376-82.

92. Villacís AG, Marcet PL, Yumiseva CA, Dotson EM, Tibayrenc M, Brenière SF, et al. Pioneer study of population genetics of Rhodnius ecuadoriensis (Hemiptera: Reduviidae) from the central coast and southern Andean regions of Ecuador. Infect Genet Evol. 2017; 53: 116-27.

93. Villacis AG, Bustillos JJ, Depickere S, Sanchez D, Yumiseva CA, Troya-Zuleta A, et al. Would tropical climatic variations impact the genetic variability of triatomines: Rhodnius ecuadoriensis, principal vector of Chagas disease in Ecuador? Acta Trop. 2020; 209: 105530.

94. Abad-Franch F, Monteiro FA, Pavan MG, Patterson JS, Bargues $\mathrm{MD}$, Zuriaga MA, et al. Under pressure: phenotypic divergence and convergence associated with microhabitat adaptations in Triatominae. Parasit Vectors 2021; 14: 195

95. Monteiro FA, Weirauch C, Felix M, Lazoski C, Abad-Franch F. Evolution, systematics, and biogeography of the Triatominae, vectors of Chagas disease. Adv Parasitol. 2018; 99: 265-344.

96. Aragão MB. Domiciliação de triatomíneos ou pré-adaptação à antropofilia e à ornitofilia? Rev Saude Publica. 1983; 17(1): 51-5.

97. Almeida CE, Lima MM, Costa J. Ecologia dos vetores. In C Galvão, org. Vetores da doença Chagas no Brasil. Curitiba: Sociedade Brasileira de Zoologia; 2014. p. 220-34.

98. Sangenito LS, Branquinha MH, Santos ALS. Funding for Chagas disease: a 10-year (2009-2018) survey. Trop Med Infect Dis. 2020; 5(2): e88.

99. Abad-Franch F, Diotaiuti L, Gurgel-Gonçalves R, Gürtler RE. Certifying the interruption of Chagas disease transmission by native vectors: cui bono? Mem Inst Oswaldo Cruz. 2013; 108(2): 251-4.

100. Picollo MI, Vassena C, Orihuela PS, Barrios S, Zaidemberg M, Zerba E. High resistance to pyrethroid insecticides associated with ineffective field treatments in Triatoma infestans (Hemiptera: Reduviidae) from Northern Argentina. J Med Entomol. 2005; 42(4): 637-42.

101. Lillioso M, Folly-Ramos E, Rocha FL, Rabinovich J, CapdevielleDulac C, Harry M, et al. High Triatoma brasiliensis densities and Trypanosoma cruzi prevalence in domestic and peridomestic habitats in the state of Rio Grande do Norte, Brazil: the source for Chagas disease outbreaks? Am J Trop Med Hyg. 2017; 96(6): 1456-9.

102. Beard CB, Pye G, Steurer FJ, Rodriguez R, Campman R, Peterson AT, et al. Chagas disease in a domestic transmission cycle in Southern Texas, USA. Emerg Infect Dis. 2003; 9(1): 103-5.

103. Dorn PL, Monroy C, Curtis A. Triatoma dimidiata (Latreille, 1811): a review of its diversity across its geographic range and the relationship among populations. Infect Genet Evol. 2007; 7(2): 343-52.

104. Ribeiro GJ, dos Santos CGS, Lanza F, Reis J, Vaccarezza F, Diniz C, et al. Wide distribution of Trypanosoma cruzi-infected triatomines in the State of Bahia, Brazil. Parasit Vectors. 2019; 12: 604.

105. Almeida CE, Folly-Ramos E, Peterson AT, Lima-Neiva V, Gumiel M, Duarte R, et al. Could the bug Triatoma sherlocki be vectoring Chagas disease in small mining communities in Bahia, Brazil? Med Vet Entomol. 2009; 23(4): 410-7.

106. Almeida CE, Oliveira HL, Correia N, Dornak LL, Gumiel M, Neiva VL, et al. Dispersion capacity of Triatoma sherlocki, Triatoma juazeirensis and laboratory-bred hybrids. Acta Trop. 2012; 122(1): 71-9.

107. Hernández C, Salazar C, Brochero H, Teherán A, Buitrago LS, Vera $\mathrm{M}$, et al. Untangling the transmission dynamics of primary and secondary vectors of Trypanosoma cruzi in Colombia: parasite infection, feeding sources and discrete typing units. Parasit Vectors. 2016; 9(1): 620 .

108. Weeks ENI, Davies C, Rosales CC, Yeo M, Gezan SA, ParraHenao G, et al. Community-based sampling methods for surveillance of the Chagas disease vector, Triatoma dimidiata (Hemiptera: Reduviidae: Triatominae). J Med Entomol. 2014; 51(5): 1035-42. 